Review article

\title{
Adverse drug reaction and concepts of drug safety in Ayurveda: An overview
}

\author{
Manjunath Ajanal ${ }^{\mathrm{a}, *}$, Shradda Nayak ${ }^{\mathrm{b}}$, Buduru Sreenivasa Prasad ${ }^{\mathrm{c}}$, Avinash Kadam ${ }^{\mathrm{d}}$ \\ ${ }^{a}$ Department of Dravyaguna E' Research Center, RGES Ayurveda Medical College and PG Research Center, Ron, Karnataka 582209, India \\ ${ }^{\mathrm{b}}$ Department of Dravyaguna, KLEU Shri BMK Ayurved Mahavidhyalaya, Belgaum, Karnataka 590003, India \\ ${ }^{c}$ KLEU Shri BMK Ayurved Mahavidhyalaya, Belgaum, Karnataka 590003, India \\ ${ }^{\mathrm{d}}$ Department of Research and Development, Rasayani Biologics Pvt Ltd, Pune 411045, India
}

\section{A R T I C L E I N F O}

\section{Article history:}

Received 13 July 2013

Accepted 8 October 2013

Available online 23 October 2013

\section{Keywords:}

Pharmacovigilance

ADR

Ayurveda

Drug safety

Abheshaja

\begin{abstract}
A B S T R A C T
Drug safety is a very basic and fundamental concept in medical practice. ADRs play an important role in assessing patient safety in any system of medicine. Pharmacovigilance study is thus significant to understand treatment outcomes. Current raised issue with respect to complementary and alternative system medicine (CAM) like Ayurveda is increased in number of safety reports along with report misinterpretation; this generates the negative impact on system. Although, Ayurveda which is holistic system of medicine from India has elaborated the causes and methods of drug-induced consequences along with preventive measures the available data in classical texts is scattered. The compilation and analysis along with modern concept drug safety is need of the hour. Present literature review was conducted from various compendium of Ayurveda and electronic data base with search terms of 'Vyapad', 'Viruddha', 'Ahita', 'herb-herb interaction', 'idiosyncrasy', 'Prakritiviruddha' etc. The reported information was analysed for the possible correlation on concept of ADR and Pharmacovigilance of current science. Overall review demonstrated that drug interaction, iatrogenic, over dose, administration of unsuitable drugs, reprehensive drug administration with respect to disease, complication from five procedural therapies (Panchakarma) and reprehensible preparation of mineral drug are nearer to the modern causes of ADR. Thus, concept of drug safety and ADR is not new to the Ayurveda. The concept "Drug which is not appropriate to be used as medicine"(Abheshaja) of Ayurveda sounds similar as that of modern pharmacovigilance.
\end{abstract}

Copyright @ 2013, InPharm Association, Published by Reed Elsevier India Pvt. Ltd. All rights reserved.

\section{Background}

The ancient Indian system of Ayurveda is practicing in India since $1500 \mathrm{BC}$, the main aim of this system is to preservation of normal health and curing the diseased one. This system has given potential importance to patient safety and benefits. In fact it is known that drug safety is a very basic and fundamental concept in medical practice.

The current raised issue with respect to Alternative medicine and Ayurveda is increasing reports of ADR related to herbal medicine $e^{1-3}$ this may be due to increase in number of people taking herbal products either as a medicine or as a nutritional supplement. Such Reports tend to sensationalise the issue and give a negative impression regarding the use of herbal medicines. Such reports

\footnotetext{
* Corresponding author. RGES Ayurveda Medical College and PG Research Center, Ron, Karnataka 582209, India.

E-mail address: manju.ajanal@gmail.com (M. Ajanal).
}

many a times neglect to identify the cause behind the event which can be pertaining to variety of issues which are already considered in Ayurveda but are neglected many a times either due to ignorance or negligence. One such article by Saper et al has done considerable damage to the reputation of Ayurveda but at the same time it has also raised several questions which needs to be addressed systematically and scientifically to avoid misinterpretation of such reports. ${ }^{4,5}$ Hence, implementation of Pharmacovigilance in Ayurveda is need of the hour to address this issue and to make system more scientific.

Pharmacovigilance plays an important role in optimizing drug safety and improving treatment outcomes. Pharmacovigilance is defined by the World Health Organization (WHO) as 'the science and activities relating to the detection, evaluation, understanding and prevention of adverse effects or any other drug-related problem. ${ }^{6}$

Ayurveda always emphasized on safe treatment which includes alleviates the disease by not instigating another disease. ${ }^{7}$ For this achievement various modalities of drug and its administration 
along with cautions and restrictions have been suggested throughout the Samhita (Texts). This proposes that the knowledge of drug safety is known to the authors of Ayurveda.

This information on drug safety and adverse drug reaction is being scattered throughout the texts of Ayurveda. The compilation and analysis along with modern concept drug safety is need of the hour. In earlier articles ${ }^{8-11}$ on Pharmacovigilance of Ayurveda has provided importance of implementation of Pharmacovigilance in Ayurveda system of medicine but these are devoid of concept of Ayurvedic ADR and drug safety. Hence, in this article we have discussed the perception of concept ADR, drug safety and their preventive measures in Ayurveda.

\section{Methods}

A search was conducted from Classical books of Ayurveda which includes Charakasamhita, Sushrutasamhita, Bhavaprakasha Nighantu etc. and electronic data base such as Google scholar, Pubmed and Pubmed Central on the following search terms 'Vyapad', 'Viruddha', 'Ahita', 'herb-herb interaction', 'idiosyncrasy', 'Prakritiviruddha' and 'Doshala'. The literature includes from classical books of Ayurveda and published journal articles. The reported information with respect to above terms were screened and analysed for the possible correlation on concept of ADR and Pharmacovigilance of modern science.

\subsection{Causes of $A D R$ as mentioned in Ayurveda}

Ayurveda texts have mentioned various causes for ADR which seems to be not much different than those explained in modern pharmacology such as, excessive effects, drug interaction, drug intolerance in susceptible patients, idiosyncrasy and drug allergy. ${ }^{12}$ The word ADR may not be found in Ayurvedic literature but the concepts and safety issues are vibrant throughout texts of Ayurveda.

Extensive literary survey demonstrated that Ayurveda has given utmost importance to safety and benefit of patient in every step of treatment which includes selection of raw drugs, collection, different processing techniques, and their proper administration in appropriately diagnosed patient. The comparative contributing factors for ADR in Ayurveda and modern medicine are presented in Table 1. Overall, different causes of adverse drug reaction told in Ayurveda can be grouped under follow headings

1. Drug interaction (Viruddadravyaprayoga)

2. Iatrogenic (Vaidhyakruti)

3. Over dose (Atimatradravyaprayoga)

4. Administration of unwholesome drugs (Ahitatamadravyas)

5. Administration of medicine in diverse pathological stages (Avastanusaradravyaprayoga)

6. Therapeutic procedural complications (Panchakarmavyapad)

7. Improper use of Rasaushadi (Medicines of mineral origin)

\subsection{Drug interactions in Ayurveda}

Drug interaction is one of the prime causes of ADR in conventional system. This may lead to enhanced or diminished effect that may be useful or harmful. ${ }^{13}$ The factors and possible ways of drug interaction in present medical practice are multiple pharmacological effects of formulations, interpathy prescriptions i.e. intake of both Ayurveda and allopathy drugs simultaneously, Use of OTC (over the counter) drugs, patient noncompliance and Drug abuse. ${ }^{14}$ Other than this, factors like Environmental chemicals such as residual insecticides, pesticides etc could also contribute to drugchemical interaction. ${ }^{15}$ Ayurveda systematically expressed the evading measures as concept of incompatibility (Viruddaahara and aushada) and diet restrictions while taking drugs (Apathyasevana in Aushadaprayogakaala).

\subsubsection{Drug-Herb interaction}

This is one of the main stream issues in relation to the ADR of particular drug. There is mis-belief that natural drugs are safe and devoid of toxicity. But this is not true as Ayurveda states that every material in the universe is medicine and thus exerts one or the other therapeutic effect if utilized properly. But injudicious use may alter the action of drug, the intensity of which may be mild to severe or unpredictable. Also activity could be synergistic, decreased,

Table 1

Comparative analysis of modern medicine and Ayurveda in relation with various factors of adverse drug reaction.

\begin{tabular}{|c|c|c|c|}
\hline Sl. no & Character & Modern medicine & Ayurvedic medicine \\
\hline 1. & Adverse drug reaction & $\begin{array}{l}\text { Unintended drug response which is } \\
\text { not documented during various } \\
\text { phases of clinical trial }\end{array}$ & $\begin{array}{l}\text { Intended drug response, the possible } \\
\text { ways and mechanism of event has } \\
\text { already been documented in various } \\
\text { texts of Ayurveda }\end{array}$ \\
\hline 2. & Causes of ADR & $\begin{array}{l}\text { Drug excessive effects, interaction, } \\
\text { drug intolerance, idiosyncrasy } \\
\text { and drug allergy }\end{array}$ & $\begin{array}{l}\text { Drug interaction, iatrogenic, over dose, } \\
\text { unwholesome drugs, drug pharmacokinetic } \\
\text { interaction, procedural complications and } \\
\text { GMP concern }\end{array}$ \\
\hline 3. & Concept of Prakriti (Constitution) & Not described & Has potential role in causing ADR \\
\hline 4. & $\begin{array}{l}\text { Alteration of drug action due to } \\
\text { exercise or mental status }\end{array}$ & No theoretical explanation available & $\begin{array}{l}\text { Alteration of drug action can be seen due } \\
\text { to physical or mental activities }\end{array}$ \\
\hline 5. & $\begin{array}{l}\text { Description of wholesome and } \\
\text { unwholesome drugs }\end{array}$ & Not described & Described \\
\hline 6. & $\begin{array}{l}\text { Improper administration of } \\
\text { therapeutic instruments }\end{array}$ & Not known to cause ADR & Known to cause failure of therapy \\
\hline 7. & GMP guidelines & $\begin{array}{l}\text { Only pertaining to manufacturing } \\
\text { of quality drugs }\end{array}$ & $\begin{array}{l}\text { Violation of any specified measures can } \\
\text { lead to diseases }\end{array}$ \\
\hline 8. & $\begin{array}{l}\text { Relevance of diet restriction } \\
\text { during drug administration }\end{array}$ & Generally not applicable & Reliant factor for therapeutic success \\
\hline 9. & Violation of therapeutic restrictions & Not related with ADR & Has potential role in causing ADR \\
\hline 10. & Over dose & $\begin{array}{l}\text { Not included in WHO definition } \\
\text { of ADR }\end{array}$ & Important factor to cause ADR \\
\hline 11. & Seasonal variation of drug action & Not described & $\begin{array}{l}\text { Variation is known to cause alteration } \\
\text { of drug action, therefore need be } \\
\text { assessed before prescribing drug }\end{array}$ \\
\hline
\end{tabular}


antagonistic action or increase in the bioavailability. Examples can be cited of bleeding tendency after intake of Phenprocoumon along with ginger, warfarin with Fenugreek, claw, garlic, mango or papaya ${ }^{16,17}$; decrease in activity of Lithium when consumed along with herbal diuretics like Tribulus terrestris, Syzygium cuminii. ${ }^{18}$ These can be bizarre reactions since interacted herb has no role in the event, as in Phenytoin along with Convolvulus pluricaulis (Shankapushpi) leading to loss on seizure control thus difficult to predict. $^{19}$

The interactions mentioned in Ayurveda can be categorized into herb with herb, herb with food, herb-animal origin drugs and herb - mineral drugs. Examples cited are listed in Table 2.

\subsubsection{Drug-exercise pharmacokinetic interaction}

This is very important and very much relevant contribution from Ayurveda and this is more significant factor to cause ADR. ${ }^{23,24}$ As the actions of some herbs are influenced by some physical activities, such include coitus, exertion, exposing to sun and getting anger are contraindicated while taking gum of Commiphora mukul. ${ }^{25}$ Some time drugs can also interact with disease conditions of the individual and the effect of these may be unintended leading to as drug-disease interaction; example can be cited as Terminalia chebula is contraindicated in pregnancy, malnourished and anorexia conditions. ${ }^{27}$

\subsection{Over dose}

According to recent FDA definition of $A D R,{ }^{28}$ over dose is prime cause of ADR. Ayurveda has given principal significance to this issue, some of which can be classified as quantitative (Dravyata), qualitative (Gunataha) and functional (Karmataha) with respective effects.

Table 2

Ayurvedic forms of drug interaction with typical examples.

\begin{tabular}{|c|c|c|c|}
\hline Sl. no & $\begin{array}{l}\text { Type of drug } \\
\text { interaction }\end{array}$ & Example & References \\
\hline 1. & $\begin{array}{l}\text { Herb-herb } \\
\text { interaction }\end{array}$ & $\begin{array}{l}\text { - Piper betel is contraindicated } \\
\text { while taking Garcinia morella } \\
\text { - Basella alba along with } \\
\text { Sesamum indicum }\end{array}$ & 7,20 \\
\hline 2. & $\begin{array}{l}\text { Herb-Food } \\
\text { interaction }\end{array}$ & $\begin{array}{l}\text { - Combination of Payasa } \\
\text { (milk preparation) and } \\
\text { Mantha (gruel) is contraindicated } \\
\text { - Wine with steamed grains } \\
\text { - Radish with milk }\end{array}$ & 7,21 \\
\hline 3. & $\begin{array}{l}\text { Herb-animal } \\
\text { origin drug } \\
\text { interaction }\end{array}$ & $\begin{array}{l}\text { - Kapotamamsa (meat of } \\
\text { pigeon) is contraindicated } \\
\text { with Sarshapataila (Brassica alba) } \\
\text { - Pork is contraindicated with } \\
\text { Narikelataila (oil of Coccus nucifera) } \\
\text { - Equal quantity of Madhu (Honey) } \\
\text { with Grutha (Ghee) is contraindicated } \\
\text { and this has been proved to produce } \\
\text { toxic effect by combination }\end{array}$ & $7,21,22$ \\
\hline 4. & $\begin{array}{l}\text { Drug-exercise } \\
\text { pharmacokinetic } \\
\text { interaction }\end{array}$ & $\begin{array}{l}\text { Maithuna (coitus), Shrama (exertion), } \\
\text { Athapa (exposing to sun) and } \\
\text { Krodha (anger) are contraindicated } \\
\text { while taking Guggulu (gum of } \\
\text { Commiphoramukul) }\end{array}$ & 7 \\
\hline 5. & $\begin{array}{l}\text { Drug-disease } \\
\text { interaction }\end{array}$ & $\begin{array}{l}\text { Haritaki (Terminalia chebula) } \\
\text { contraindicated in pregnancy, } \\
\text { malnourished, anorexia after } \\
\text { blood letting } \\
\text { - Rasayana (rejuvenative therapy) } \\
\text { contraindicated in Anatmavan } \\
\text { (ignorance), Alasi (lazy), Daridra } \\
\text { (poverty), Pramadi (intoxicated), } \\
\text { Vyasani (drug addicted), Papi } \\
\text { (unrighteousness), Beshajapamani } \\
\text { (one who insult the medicines) }\end{array}$ & $22,26,27$ \\
\hline
\end{tabular}

\subsubsection{Quantitative over dose (Dravyataha atisevana)}

Disorders like impotency, dryness of mouth, refractive error, lean, fainting and diarrhoea are result of over usage of Commiphoramukul, curd, Piper longum, salt, alkalis and administration of single flavoured items (Ekarasasevana) ${ }^{21,25}$.

\subsubsection{Qualitative over dose (Gunataha atisevana)}

Over usage of similar properties of drug such as hot (Ushnavirya) or heavy (Guru) potency drugs which produce aggravation of specific quality in body. Similarly over administration of Pipper longum, alkalis and salts ${ }^{7}$ and administration of Sulphur along with alkalis or sour item is known to aggravate the disease condition. ${ }^{20}$

\subsubsection{Functional over dose (Karmataha atisevana)}

Excess intake of drug, which are similar in their action on human body, like administration of paste of Operculina turpethum along with Ichhabhedi ras (Herbal formulation) causes drastic purgation (This ADR has been reported to peripheral Pharmacovigilance for ASU drugs, KLE Ayurveda hospital Belgaum, Karnataka. India. Dated 25-08-2010).

\subsection{Administration of unwholesome drugs (Ahitatamadravyas)}

Unwholesome (Ahitatama) drugs are not suitable for therapeutic purpose, and administration of such drugs may induce the failure of treatment which intern leading to unintended drug event. Many a times tangent property of drug i.e. by utilizing analogous property of drugs with diseases lead to ADRs by aggravating the original conditions as in blood vitiating (Rakta doshaka) property of Tamarindus indica $^{26}$ and Sapindus mangifera ${ }^{29}$; asthenia, blister producing capacity of Semicarpus anacardium ${ }^{25}$ are few examples of such ADRs.

\subsection{Administration of medicine in diverse pathological stages (Avastanusara dravyaprayoga)}

Irrational prescription of Ayurvedic medicines could lead to unintended drug event. Possibly, these may interact with pathological condition. Ayurveda lays special emphasis on factors which need to be analysed before prescribing drug. Which includes, individual humours (Dosha), individual constitution (Prakriti), time (Kaala), age (Vaya), digestive capacity (Agni) etc. ${ }^{29}$ this indicates the deep awareness of avoiding drug-induced problems.

These factors can be classified as 'Contradicted drugs on disease (Roga/avastaviruddadravyaprayoga)', 'Contradicted drugs on season and time (kaalaviruddadravyaprayoga)' and 'Contradicted drugs on individual constitution (Prakritiviruddadravyaprayoga)'.

Examples of 'Contradicted drugs on disease' include, astringent drugs (Kashaya rasa) contraindicated in fever of recent origin (Tarunajwara), ${ }^{7}$ poultice in breast abscess. ${ }^{22}$

Administration of Fresh ginger in summer and autumn ${ }^{27}$; application of collyrium after meals, head bath and in night time, ${ }^{22}$; Consumption of curd at night, autumn, summer, or spring ${ }^{27}$;application of poultice in Night time ${ }^{21}$ are the examples of contradicted drugs on season and time.

\subsection{Idiosyncrasy}

These occur in small fraction of people $(<5 \%)$ and is unrelated to the drug's pharmacologic effect, with no relation to dose and occurs with inconsistent temporal patterns in relation to drug exposure. ${ }^{30}$ The predicted causes include metabolic polymorphism, allergy, and immunological hypersensitivity but many a times the cause is unknown. There are few proposed theories such as "Host vulnerability". ${ }^{31}$ According to this theory effect of drug differs from person to person since unlike of individual constant within their group. 
Same concept has been explained in Ayurveda in one term called Prakriti (Human constitution).

\subsubsection{Contradicted drugs on individual constitution (Prakriti virudda dravyaprayoga)}

Ayurveda has mentioned a unique concept of human constitution (Prakriti). Based on this concept Ayurveda thus, stressed more on individualistic treatment. Wherein, assessment of constitution is very much important factor to considered before prescription of medication. Thus, administrations of drug, according to their constitution have beneficial effects in relation with safety and efficacy. Few recent studies have shown that, persons belongs to different Prakriti will have different in their rate of drug metabolism which associated with DME (drug metabolizing enzyme) polymorphism. ${ }^{32}$ This concept of phenotypic classification of patients as per Prakriti has an important role to play in determining drug safety. We can find several examples related to contraindication of particular drugs in people of some specific prakriti. As Semicarpus anacardium and Ferula northex are known to cure skin diseases. At the same time, which contraindicated in Pitta constitution, as these are potency of vitiating Pitta ${ }^{25}$ similarly, Dattura metal have Vata vitiating character hence, not advisable in Vata diseases. ${ }^{27}$ This clearly suggested that the guidelines of drug administration mentioned in Ayurveda texts have obviously taken in to consideration the concept of Phenotype-genotype correlation and drug safety.

Exploring this concept of phenotypic classification according to Ayurveda may provide several clues for identifying of underlying metabolic variability leading to difference in drug response. Such drug responses can be incorporated under idiosyncrasy.

\subsection{Panchakarma (procedural therapies) and their role in ADR}

Edwards RI et al recent definition of $\mathrm{ADR}^{33}$ includes any unintended response from drug or materials used to diagnose or treat. Thus, any unintended responses from Panchakarma (Procedural therapies) can be included in this category of ADR.

Panchakarma (Procedural therapies) are detoxification (Shodana) therapies used to treat various diseases and many rules and precautionary measures are listed in Ayurveda. These are termed as inadequate (Ayoga), excess administration of therapy (Atiyoga), Contraindications (Anarha) and Complications (Vyapad) while carrying out these procedures. Such consequences are mostly because of faulty preparation of drug and improper assessment of patient resulting in failure of treatment or by iatrogenic.

These can be classified into materialistic, Drug-induced (Dravyataha), iatrogenic, and patient faults (Rogisambandi).

Materialistic causes include faulty preparation of Basthi (enema procedure) instrument (Basthi Yantradoshas) as defective nozzles ${ }^{22}$ and defective enema can.?

Drug-induced (Dravyata) examples can be quoted as inferior substitute of Operculina turpethum this administration will lead to drastic purgative and aggravating the disease condition (Utkarshana), unconsciousness, fainting, burning sensation, giddiness. ${ }^{31}$

Iatrogenic events include wrong selection of drug with respect to pathology, complications from therapist ${ }^{36}$ and improper patient examination with respective drug administration.

Rogisambandi (patient related) includes improper observance of treatment by patient, faithless patient (Abhishakvasya) and reprehensive pursue of diet restriction (Apatyasevana) leading to failure of respective drugs or therapy.

\subsection{Rasaushadi (mineral drugs) and their role in Ayurvedic ADR}

It is a common notion among the public and modern doctors that mineral drugs are toxic since they are heavy metals. These sayings have been potentiated by the recent Saper B Et.al ${ }^{4}$ article, but later Dept. of AYUSH (Ayurveda, Unani and Siddha) has found various flaws and bias in reported results against Ayurvedic medicines. ${ }^{5}$ If at all these consequences persist it is due to administration of substandard drugs (Ashoditadravya/hina dravyaprayoga), over dose and lack of textual knowledge. Few examples are death, abdomen pain, loss of lustre, chest pain, intoxicating and GI bleeding by administration of Improper prepared of iron calyx (Apakva Lohabhasma). ${ }^{34}$

Over dose is one of major saddle in drug events of Ayurvedic mineral drug. Many a times, this over dose could be unintentional in nature since it is common to prescribe multiple Herbo-mineral drugs in combination. Hence, more possibility of combining the similar drugs in different formulations thus, tendency of additive greater drug dose are more. Ayurveda uses deadly poisons as medicine which are Arsenic, mercury, lead etc. these therapeutic administration dose is minimal. Slight changes in dose could lead to dire event or death e.g. over dose of arsenic, ${ }^{35}$ hair fall property of orpiment. $^{25}$ Along with this, Ayurveda also has given similar importance to diet restrictions while administering mineral drug. As these drugs have potential chance to interact with food. E.g. can be cited of Dolichos biflorus and meat of dove contraindicated while administering Black bitumen (Shilajatu). ${ }^{22}$

\subsection{Preventive measures}

Ayurveda emphasizes on safe treatment hence, to prevent the drug-induced illness many restrictions have been suggested which include, GMP (Good Clinical Practices) concern on administration, prescription of expired medicines, knowledge of inappropriate drug, $^{34}$ examination of patient and disease before prescription (Roga pareeksha).

Qualities of excellent medicine are, those which are effective in small dose, therapeutically active, have multiple utility, do not produce any ADR, easily digestible and acceptable. ${ }^{7}$ For achieving this one should follow the GMP guidelines mentioned in texts of Ayurveda.

\subsubsection{GMP guidelines in Ayurveda}

It begins from standardization of raw material to finish product, which are identification of raw drugs, ${ }^{7}$ quality checking, method of storage $^{22}$ and method of preparation. Once product is prepared, it must pass the pharmaceutical standards. ${ }^{36}$ Special care have been suggested while preparing mineral and poisonous drugs which includes purifications of raw materials, different processing technique $^{35}$ and incineration before converting to dosage form. This quality concerns are controlled by formulary guidelines called AFI (Ayurvedic formulary of India) developed by dept of AYUSH (Ayurveda, Unani, Siddha) and CCRAS (Central council for Research in Ayurveda and Siddha).

If medicine is good in quality then to minimize the ADR and success in therapeutic, one must assess the 'Constitution (Prakriti)', 'Age (Vaya)', 'disease (Vikruti)', 'tolerance (Satmya)', 'capacity for exercise (Vyayamashakti)', 'tissue quality (Saara)','physical proportion (samhanana)' and strength (Bala), Tripod patient examination (Trividapareeksha), ${ }^{7}$ six types of disease examination (Shadvidapareeksha), ${ }^{22}$ eight and ten different types of patient examinations (Ashtavida and Dashavidapareeksha). ${ }^{29,37}$

\subsubsection{Guidelines for drug administration in Ayurveda}

Ayurvedic pharmacology also include time of drug administration (Aushadasevanakaala), drug adjuvant (Anupaana) and diet/ regimen restrictions (Pathya-apathyasevana) for proper, effective and specific action on target site. Most importantly, it helps to overcome the untoward or toxic effects of the drug. 
Along with these Ayurveda, has also highlighted drug tangent qualities, sequence of interaction, consequences of over dose, poison and Panchakarama Vyapad (secondary effect) for better therapeutic success in conjunction with minimize drug-induced event. Hence, it is duty of physician to use his 'source of knowledge' (Yukti), 'Purpose of the use of knowledge' (Artha) and 'Subject where knowledge is used' (Abhipretya) while handling these drugs or diet.'

For monitoring and controlling over the reporting and reported drug events from Ayurveda, Siddha and Unani (ASU) drugs in India the Dept. of AYUSH and MoH\&FW (Ministry of health and Family welfare) has recently initiated Pharmacovigilance programme for ASU drugs.

\section{Conclusion}

Drug safety continues to play an important role in patient care and disease management in any branch of medicine. When it comes to issue of safety related to herbal and Ayurveda medicine, the matter becomes very important as it shakes the beliefs of patients related to safety of Ayurveda. It has to be understood that use of all sorts of medicines are associated with some degree of risk, and it totally lies with the treating physicians to trade-off between the benefits and the potential risk. This risk can be considerably reduced by use of good quality medications and following various guidelines and instructions mentioned in Ayurveda classics related to administration of drugs. To achieve this it is very important to understand and study the principles of drug safety mentioned in Ayurveda. We can see that Ayurveda has very elaborate explanation about ADR and ways to prevent it. A rich textual knowledge is necessary while practicing to minimize the occurrence of ADRs. There is also a need for extensive research to be carried so as to understand the reasoning and concept behind the classical principles related to drug administration and safety. Such studies can help to explore new paradigm related with pharmacokinetics, pharmacodynamics and pharmacogenomics. Spontaneous reporting of ADR related to Ayurveda treatments will also play a very important role in providing signals and formulating new research questions.

\section{Conflicts of interest}

All authors have none to declare.

\section{Acknowledgement}

Authors are grateful to the coordinator of the Peripheral Pharmacovigilance Centre for Ayurveda, Siddha, and Unani Drugs, Karnataka state and KLE Ayurveda Hospital Belgaum, Karnataka, India. for their support in generating data.

\section{References}

1. Jose J, Rao PG, Kamath MS, Jimmy B. Drug safety reports on complementary and alternative medicines (ayurvedic and homeopathic medicines) by a spontaneous reporting program in a tertiary care hospital. J Altern Complement Med. 2009;15:793-797.

2. Wal P, Wal A, Gupta S, Sharma G, Rai A. Pharmacovigilance of herbal products in India. J Young Pharm. 2011;3:256-258.

3. Ajanal M, Kadam A, Nayak SU. Skin rash on site of application of Dashanga Lepa (polyherbal formulation): a rare and unexpected drug reaction. Anc Sci Life. 2012;31:129-131.
4. Saper RB, Phillips RS, Sehgal A, et al. Lead, mercury, and arsenic in US- and Indian-manufactured Ayurvedic medicines sold via the Internet. JAMA 2008;300:915-923.

5. Ministry of Health and Family Welfare [online] 2008 September 02; 2012 Nov 13 Available from: http://pib.nic.in/newsite/erelease.aspx?relid $=42213$.

6. World Health Organization [online] 2002; 2012 Nov 16. Available from: http:// apps.who.int/medicinedocs/en/d/Js4893e/9.html.

7. Acharya JT, ed. "Chikitsastana" Charaka Samhita. 5th ed. Varanasi: Chaukhambha Sanskrit Sansthan; 2006, 647, 412, 138-150, 22, 234, 276, 702,693, 704, 247.

8. Thatte U, Bhalerao S. Pharmacovigilance of ayurvedic medicine in India. Indian J Pharmaco. 2008;40:S10-S12.

9. Bhaleroa S, Thatte U. Proceedings of Pre Conference Workshop "Pharamacovigilance of Ayurvedic Medicines". 2006.

10. Chaudhary A, Singh N, Kumar N. Pharmacovigilance: boon for the safety and efficacy of Ayurvedic formulations. J Ayurveda Integr Med. 2010;1:251-256.

11. Rastogi S. Why and how? Addressing to the two most pertinent questions about pharmacovigilance in Ayurveda. Int J Ayurveda Res. 2011;2:48-52.

12. Satoskar RS, Bhandarkar SD, Rege NN. Pharmacology and pharmacotherapeutics. 21st ed. Mumbai: Popular Prakashan Private Limited; 2009:38.

13. Hussar DA, ed. Drug interactions. Ramington. The Science and Practice of Phar macy. vol. 2. New Delhi: Wolters Kluwer health; 2007:1889, 1st Indian reprint.

14. Katzung GB. Basic \& Clinical Pharmacology. 10th International ed. New Delhi: McGraw Hill; 2007:73.

15. Vesell SE, eds. Methods to Assess Drug-Drug and Drug - Chemical Interactions: Problems that Arise in their Application to the Prediction of Health Hazards from Exposure to Multiple Environmental Chemicals. In: Vouk BV, Butler CG, Upton CA, Parke VD, Asher CS. eds. Methods for Assessing the Effects of Mixtures of Chemicals. New York: John Wiley \& Sons; 1987: 795-811.

16. Kruth P, Brosi E, Fux R, Morike K, Gleiter CH. Ginger associated over anticoagulation by phenprocoumon. Ann Pharmacother. 2004;38:257-260.

17. Qureshi S, Al Diab A, Al-Anazi AF, et al. Negative aspects of the beneficial herbs: an over view. J Herb Med Toxicol. 2012;6:1-14.

18. Pyevich D, Bogenschutz MP. Herbal diuretics and lithium toxicity. Am J Psychiatry. 2001;158:1329.

19. Dandekar UP, Chandra RS, Dalvi SS, et al. Analysis of a clinically important interaction between phenytoin and shankhapushpi, an Ayurvedic preparation. J Ethnopharma-col. 1992;35:285-288.

20. Ambikadatta SS, ed. Rasaratnasamucchaya of Rasa Vagbhata. 9th ed. Varanasi: Chaukhambaamarabharatiprakashan; 1995:62-79 [Chapter 3].

21. Acharya YT, ed. "Sutra Stana" Sushruta Samhita. 8th ed. Varanasi: Choukhambaorientalia; 2005, 96, 185, 85, 43, 505, 469, 488, 529, 456.

22. Annapoorna A, Anilakumar RK, Farhath Khanum, Anjaneya MN, Bawa S. Studies on physicochemical characteristics of heated honey, honey mixed with ghee and their food consumption pattern by rats. AYU. 2010;31:141-145.

23. Lenz TL. The effects of high physical activity on pharmacokinetic drug interactions. Expert Opin Drug MetabToxicol. 2011;7:257-266.

24. Lenz TL, Lenz NJ, Faulkner MA. Potential interactions between exercise and drug therapy. Sports Med. 2004;34:293-306.

25. Sharma PV, ed. Priyanighantu. 1st ed. vol. 20. Varanasi (UP): Chaukhamba Samskruta Pratistana; 2004:156.

26. Sharma PV, ed. Dhanvantari Nighantu of Dhanvantari. 2nd ed. vol. 54. Varanasi: Chaukhambha orintalia; 1979:153.

27. Pandey GS. In: Bhavaprakshnighantu of Bhavamisra. Varanasi (UP): Chaukhambabharati Academy; 2004, 7, 14, 766, 317.

28. U.S. Food and Drug Administration [online] 2012 Jan 04; 2012 Mar 23. Available from: www.accessdata.fda.gov/scripts/cdrh/cfdocs/cfcfr/CFRSearch.cfm?CFRPart=314.

29. Kaiyadeva. Kaiyadeva of Kaiyadevanighantu. In: Sharma PV, Sharma GP, eds 1st ed. Varanasi (UP): Chaukhambha orintalia; 2009, 64, 188.

30. Roth Robert A, Luyendyk, Maddox James P, Ganey EP. Perspectives in pharmacology inflammation and drug idiosyncrasy - is there a connection? Am Soc Pharmac Exper Thera. 2003;1:1-8.

31. Zimmerman HJ. Hepatotoxicity. Dis Mon. 1993;39:675-787.

32. Ghodke Y, Joshi K, Patwardhan B. Traditional medicine to modern pharmacogenomics: Ayurveda Prakriti type and CYP2C19 gene polymorphism associated with the metabolic variability. Evid Based Complement Alternat Med. 2011;2011:1-5.

33. Edwards RI, Aronson JK. Adverse drug reactions: definitions, diagnosis, and management. The Lancet. 2000:356:1255-1259.

34. Acharya M, ed. Ayurveda Prakash; Suvarnadidathupadatu. 2nd ed. Varanasi: The Chowkhamba Vidyabhawan; 1962:363 [Chapter 3, verse 225].

35. Sharma S. Rasatarangini. 11th ed. New Delhi: Motilal Banaras Publication; 1979, 269, 21-22.

36. Shastri P, Vidhyasagar, eds. Sharangadhar Asamhita of Sharangadhara, Madhyamakhanda; Avalehakalpana. Varanasi: Chaukhambaorientalia; 2005:207 [Chapter 8, verse 3].

37. Shastri B, ed. Yogaratnakara, Purvardakhanda, Roginamastasthananipareeksha. Varanasi: Chaukhambhaprakashan; 2008:p.5. Verse-1. 